\title{
Community development in the school workplace
}

\author{
Citation for published version (APA):
}

Brouwer, P., Brekelmans, M., Nieuwenhuis, A. F. M., \& Simons, R-J. (2012). Community development in the school workplace. International Journal of Educational Management, 26(4), 403-418.

https://doi.org/10.1108/09513541211227809

DOI:

10.1108/09513541211227809

Document status and date:

Published: 11/05/2012

Document Version:

Publisher's PDF, also known as Version of record

Please check the document version of this publication:

- A submitted manuscript is the version of the article upon submission and before peer-review. There can be important differences between the submitted version and the official published version of record. People interested in the research are advised to contact the author for the final version of the publication, or visit the DOI to the publisher's website.

- The final author version and the galley proof are versions of the publication after peer review.

- The final published version features the final layout of the paper including the volume, issue and page numbers.

Link to publication

\section{General rights}

Copyright and moral rights for the publications made accessible in the public portal are retained by the authors and/or other copyright owners and it is a condition of accessing publications that users recognise and abide by the legal requirements associated with these rights.

- Users may download and print one copy of any publication from the public portal for the purpose of private study or research.

- You may not further distribute the material or use it for any profit-making activity or commercial gain

- You may freely distribute the URL identifying the publication in the public portal.

If the publication is distributed under the terms of Article $25 f a$ of the Dutch Copyright Act, indicated by the "Taverne" license above, please follow below link for the End User Agreement:

https://www.ou.nl/taverne-agreement

Take down policy

If you believe that this document breaches copyright please contact us at:

pure-support@ou.nl

providing details and we will investigate your claim.

Downloaded from https://research.ou.nl/ on date: 26 Apr. 2023 


\section{e emeraldinsight}

\section{International Journal of Educational Management}

Community development in the school workplace

Patricia Brouwer Mieke Brekelmans Loek Nieuwenhuis Robert-Jan Simons

\section{Article information:}

To cite this document:

Patricia Brouwer Mieke Brekelmans Loek Nieuwenhuis Robert-Jan Simons, (2012),"Community development in the school workplace", International Journal of Educational Management, Vol. 26 Iss 4 pp. $403-418$ Permanent link to this document:

http://dx.doi.org/10.1108/09513541211227809

Downloaded on: 26 March 2017, At: 00:48 (PT)

References: this document contains references to 36 other documents.

To copy this document: permissions@emeraldinsight.com

The fulltext of this document has been downloaded 857 times since 2012*

\section{Users who downloaded this article also downloaded:}

(2012),"Communities of practice in the school workplace", Journal of Educational Administration, Vol. 50 Iss 3 pp. 346-364 http://dx.doi.org/10.1108/09578231211223347

(1997),"Active partners: education and community development", International Journal of Social Economics, Vol. 24 Iss 11 pp. 1290-1301 http://dx.doi.org/10.1108/03068299710193615

Access to this document was granted through an Emerald subscription provided by emerald-srm:302097 [] For Authors

If you would like to write for this, or any other Emerald publication, then please use our Emerald for Authors service information about how to choose which publication to write for and submission guidelines are available for all. Please visit www. emeraldinsight. com/ authors for more information.

\section{About Emerald www.emeraldinsight.com}

Emerald is a global publisher linking research and practice to the benefit of society. The company manages a portfolio of more than 290 journals and over 2,350 books and book series volumes, as well as providing an extensive range of online products and additional customer resources and services.

Emerald is both COUNTER 4 and TRANSFER compliant. The organization is a partner of the Committee on Publication Ethics (COPE) and also works with Portico and the LOCKSS initiative for digital archive preservation.

*Related content and download information correct at time of download. 


\section{Community development in the school workplace}

\section{Community development in the school}

Patricia Brouwer

Centre for Expertise in Vocational Education and Training, Utrecht, The Netherlands

Mieke Brekelmans

Faculty of Social and Behavioural Sciences, Utrecht University, Utrecht, The Netherlands

Loek Nieuwenhuis

Ruud de Moor Centre, Open University, Heerlen, The Netherlands, and

Robert-Jan Simons

Centre for Teaching and Learning, Utrecht University, Utrecht, The Netherlands

\begin{abstract}
Purpose - The aim of this study is to explore whether and to what degree community development of teacher teams takes place and how community development comes about, that is, what community-building efforts teacher teams undertake.

Design/methodology/approach - Using a multi method approach, quantitative and qualitative data were gathered from seven interdisciplinary teacher teams in a secondary school during one school year. Teachers' perceptions of community development were complemented with video-observations of team meetings by relative outsiders.

Findings - Data showed that the teacher teams undertook a wide variety and amount of community-building efforts. However, community development of the teacher teams as perceived by the teachers was limited. Relative outsiders observed some community development.

Practical implications - From the findings the authors conclude that school managers could play a more proactive role in supporting teacher teams' community-building efforts. Strategies embedding community-building into the culture and policy of the school, including diagnosing, custom-made support and making efforts explicit, could be effective.

Originality/value - The current study takes a long-term approach, investigating the community development of teacher teams during the course of one school year. In addition, community development is measured using two perspectives, i.e. that of the community members and that of the relative outsider.
\end{abstract}

Keywords Community development, Community-building, Schools, Teacher collaboration, Community of practice, Teacher teams, Communities, Teachers

Paper type Research paper

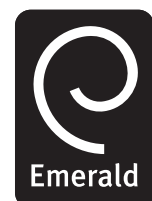

The authors would like to thank the anonymous reviewers for their helpful comments on an earlier version of this manuscript. They wish to acknowledge the work and contribution of colleagues from the research team: researcher 1 to researcher 10. The authors would like to thank the teachers in this project, who gave generously of their time. This research is funded by the Netherlands Organisation for Scientific Research and Dutch Programme Council for Educational Research.
International Journal of Educational Management

Vol. 26 No. 4, 2012 pp. $403-418$

(C) Emerald Group Publishing Limited 0951-354X 
IJEM

26,4

404

\section{Introduction}

Internationally, schools for secondary education have seen themselves confronted with reforms pertaining to changing curriculum frameworks, new designs for teachers' professional development and the changing role of teachers (Darling-Hammond and McLaughlin, 1995). More specifically, reforms that underlie the increase in collective action between teachers include collective teaching, development of thematic lesson material, coherence between subject areas, and distributed decision-making. These reforms call for consultation and coordination between teachers. Teachers need to share responsibility and authority for decision-making about their common practices (Hargreaves and Dawe, 1990). Therefore, to deal with recent reforms and the accompanying complexity of work, ongoing collaboration between teachers has become more important.

In recent years, teacher collaboration has received more attention from scholars (Achinstein, 2002). An array of scholars and reformers has called for the strengthening of collaboration between teachers by means of promoting communities of teachers in schools (Levine and Marcus, 2010; James et al., 2007). The term "communities of teachers" refers to "teachers" collective engagement in sustained efforts to improve practices' (Louis et al., 1996, p. 758). An argument for promoting communities of teachers is that communities foster collaboration to be more than an occasional exchange between teachers. Communities embed teacher collaboration into the culture of the school (Vescio et al., 2008), making collaboration expected, inclusive, genuine, and ongoing (Seashore et al., 2003). This is illustrated by a study by Bolam et al. (2005), in which teachers reported an increase in collaboration as they organised their work according to a community. This evidence suggests that organising and stimulating teachers to work together as a community is a promising strategy for school management to reinforce collaboration between teachers.

Although there is a growing awareness of the potentially strong role of communities, empirical research about how teacher communities in the school workplace function is largely absent (Imants, 2003; Westheimer, 1999). In a review on teacher communities in secondary education Lomos et al. (2011) conclude that they:

[...] consider it desirable to conduct more research into the functioning of professional community in the day-to-day practices within schools. It would be interesting to see whether teachers have actually integrated the professional community approach into their daily practices on their own initiative rather than in response to external measures of change or governmental pressure (Lomos et al., 2011, p. 140).

In this study, we want to investigate the issue of whether communities of teachers develop in the current school workplace context and if so, how community development comes about. The aim of this study is twofold. The first aim is to explore whether and to what extent community development of teacher teams actually takes place during an extended period of time. The second aim of this study is to explore the community-building efforts that teacher teams undertake.

\section{Theoretical framework}

2.1 Community of practice

Teacher teams in schools have a practice-oriented nature, since they usually develop around a shared work objective (Skerrett, 2010). Therefore, a practice-oriented conception of community seems most suitable in this study. Works by Jean Lave and 
Etienne Wenger (Lave and Wenger, 1991; Wenger, 1998) have developed the concept of communities of practice to describe sites where people jointly construct, transform, conserve, and/or negotiate the meanings of practices. Communities of practice are groups of people who share a concern or a passion for something they do and learn how to do things better as they interact regularly (Wenger, 1998). A community of practice defines itself along three dimensions (Wenger, 1998). Admiraal and Lockhorst (2010) developed indicators to further specify the rather abstract community of practice dimensions (Li et al., 2009).

Mutual engagement binds members of the community together into a social entity. Mutual engagement creates relationships among members; it connects them in ways that can become deeper than more superficial similarities such as personal features or social categories. Being included in "what matters" in a group is a requirement for being engaged in a community's practice. Based on Admiraal and Lockhorst (2010), we formulated the following indicators for this dimension:

- Identification: the extent to which members identify with the group.

- Multi-perspective contribution: the degree to which there is room for multiple perspectives in contributions to the group.

- Mutual trust and responsibility: the degree of security of the community in telling the truth; the degree to which group members feel socially responsible for the group and individual members.

- Social ties: the strength of the social bond that group members share.

Shared repertoire refers to the shared set of communal resources such as routines, words, tools, ways of doing things, stories, and concepts the community develops. The concepts, language and tools embody the history of the community and its perspective on the world. The repertoire of a community is a resource for the negotiation of meaning. Based on Admiraal and Lockhorst (2010), we formulated the following indicators for this dimension:

- Intellectual building: the degree to which members of the group constructively build on each other during discussions.

- Regulation of interaction: the degree to which the interaction in the group is organised, discussed and reflected on.

- Role-taking: the degree to which group members take up roles, tasks, and positions and accept these from others.

- Dynamic effort: the degree of flexibility with which group members look at differences in commitment, being active in discussion and the performance of tasks.

Joint enterprise is the collectively developed understanding of what the community is about and is the result of a collective process of continuous negotiation. It creates among team members' relations of mutual accountability that become an integral part of the practice. Based on Admiraal and Lockhorst (2010), we formulated the following indicators for this dimension:

- Commitment to domain: the degree of commitment of group members to the content domain of the shared work objective.

\section{Community development in the school}

405 
IJEM

26,4

406

- Common ground in concept: the degree to which group members have mutual understanding of concepts, and are aware of possible differences in understanding.

- Collective goal: the degree to which group members build on each other with the aim of reaching something collectively.

- Shared knowledge: the degree of development of shared knowledge, clear and agreed, and the degree of being able to use and expand this knowledge.

\subsection{Community development}

In literature it is suggested that communities of practices are not static entities; communities continuously evolve and change (see for instance Wenger, 1998; Grossman et al., 2001). A community of practice is a long-term enterprise that is located in the school workplace (Hindin et al., 2007). Over time, community members develop a common sense of identity (i.e. mutual engagement), they develop personal relationships and established ways of interacting (i.e. shared repertoire), and they also develop a unique perspective on their topic as well as a body of common knowledge, practices and approaches (i.e. joint enterprise). Studies on community development have mainly focused on fostering newly composed groups of teachers. In the context of teacher teams' current actual practice, however, the issue of whether teams' mutual engagement, shared repertoire, and shared domain develops over time, would be interesting to investigate. Hence, the first research question we want to answer is:

RQ1. To what degree does community development of teacher teams take place?

In the current study, community development is viewed as the change in degree of mutual engagement, degree of shared repertoire, and degree of joint enterprise of the teacher teams over an extended period of time.

\subsection{Community building}

Besides a focus in the current study on the question if community development takes place, we also focus on how this community development comes about through community building. Community building refers to ongoing efforts (activities and/or procedures) that strengthen the community of practice (Weil, 1996). Based on literature research, eight community-building principles were derived that may be related to strengthening communities of practice in the school workplace. More specifically, these eight community-building principles may lead to the development of the mutual engagement, shared repertoire, and joint enterprise of communities. The community-building principles are as follows:

(1) Determine group goals, i.e. shared goals, related to tasks and/or vision.

(2) Determine group norms, i.e. shared rules and norms for engagement, functional as well as social.

(3) Organise group roles by a division of roles related to tasks, expertise, and/or personality.

(4) Stimulate a critical reflective attitude by stimulating a culture of structural critical evaluation of team practice. 
(5) Develop mutual trust, i.e. a positive expectation between team members.

(6) Promote ownership by stimulating a sense of ownership and commitment to team responsibilities and tasks.

(7) Promote perceived interdependence by stimulating awareness of mutual dependence between team members for achieving tasks.

(8) Stimulate a collective memory by organising an accessible environment for team documents.

Because less is known about which of these eight community-building principles teacher teams engage in the context of current actual practice, we formulated a second research question:

RQ2. To what extent do teacher teams engage in the eight community-building principles - and perhaps other principles?

Figure 1 depicts the assumed relationships behind the central concepts in the research questions.

In studies on stimulating or designing for community development, the potential of community-building efforts is generally acknowledged, i.e. community-building has been hypothesised to foster the development of communities (see for instance Conley et al., 2004; Kain, 1998; Palincsar et al., 1998; Wageman et al., 2005; Wilson et al., 2004). Our research questions relate to the hypothesis that teacher teams' engagement in community-building efforts will result in community development, in other words, will result in a change in teams' mutual engagement, shared repertoire, and joint enterprise.

\section{Method}

As not much is known yet about community development and community-building efforts in teacher teams, a mixed methods approach was used, i.e. qualitative and quantitative research methods were used in a single study (Johnson and Onwuegbuzie,

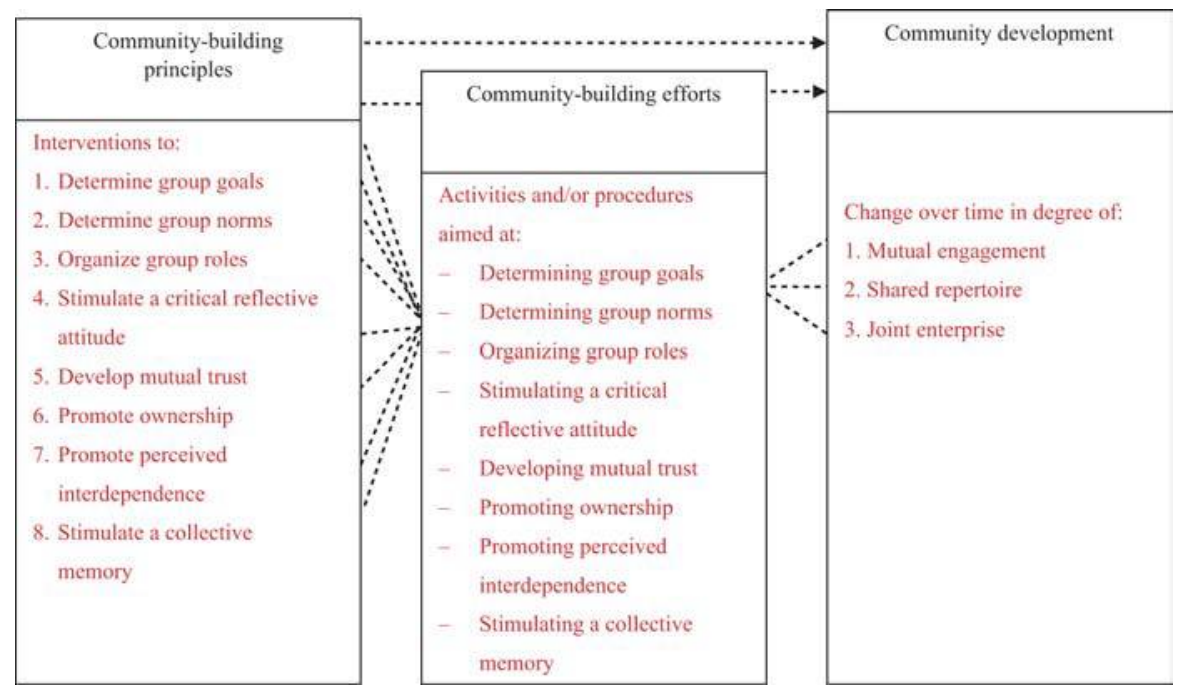

Community development in the school

407 
IJEM

26,4

408

Table I.

Team member characteristics
2004). Data from seven teacher teams (72 teachers) in one school were gathered within the school year of 2008-2009. With regard to community development, one school year was considered an extended period of time.

\subsection{Case selection}

Case selection was based on theoretical sampling (Eisenhardt, 1989). The criterion was interdependence between teachers, based on the assumption that community development requires a context of interdependence (Little, 1990). In this context teachers have to collaborate on an ongoing basis because they have only indirect control over outcomes, and their actions depend on the actions of other team members (Weick, 1979). This resulted in the choice of seven interdisciplinary teacher teams that satisfy the interdependence criterion, because in these teams teachers from different disciplines are mutually dependent in developing a thematic curriculum. To ensure contextual comparison across teacher teams, multiple interdisciplinary teams from one secondary school were chosen.

\subsection{Cases}

The setting of this study was a secondary school located in a large city in the Netherlands, established in 2002. Teams were self-directive and each responsible for approximately 100 students from one grade-level. Students were educated by means of team teaching, a type of education in which multiple teachers work together while providing and organising education. Team leaders served as middle managers in the school and were responsible for the ongoing functioning of their teams. Each team met twice a week. In the first meeting, chaired by the team leader, teachers discussed the organisation of the education as well as students. In the second meeting, chaired by the education architect, the teachers developed thematic education. The education architect was responsible for developing thematic lesson material with his/her team. Team member characteristics are described in Table I.

\subsection{Instrumentation and analysis}

3.3.1 Community development. To measure community development, i.e. changes in the degree of mutual engagement, shared repertoire, and joint enterprise, data were gathered at the beginning and end of the school year. Two perspectives were used. The first is the teachers' perception of the community of practice dimensions, related to

\begin{tabular}{crccccc}
\hline Team & $n$ & $\begin{array}{c}\text { Percentage of } \\
\text { male team } \\
\text { members }\end{array}$ & $\begin{array}{c}\text { Percentage of teachers } \\
\text { with a bachelor's degree } \\
\text { (vs master's degree) }\end{array}$ & $\begin{array}{c}\text { Average } \\
\text { occupational } \\
\text { experience in years }\end{array}$ & $\begin{array}{c}\text { Average } \\
\text { tenure in } \\
\text { years }\end{array}$ & $\begin{array}{c}\text { Average } \\
\text { age in } \\
\text { years }\end{array}$ \\
\hline 1 & 10 & 30 & 100 & 10 & 2 & 36 \\
2 & 11 & 63 & 87 & 6 & 4 & 37 \\
3 & 11 & 40 & 90 & 9 & 3 & 38 \\
4 & 9 & 43 & 43 & 5 & 3 & 34 \\
5 & 9 & 86 & 86 & 13 & 3 & 43 \\
6 & 8 & 71 & 100 & 9 & 4 & 46 \\
7 & 14 & 69 & 46 & 10 & 4 & 41 \\
\hline
\end{tabular}


formal and informal collaborative activities that take place between team members. The second perspective is observation by a relative outsider of the behaviour of the teachers related to the community of practice dimensions during team meetings.

Teacher perception was measured using a questionnaire (Table II) developed by a team of researchers, based on Admiraal and Lockhorst (2010), and Burroughs and Eby (1998). The questionnaire was administered at the beginning and end of the school year. Perception of mutual engagement was measured with six items (for example: "there is a good team spirit in this team"). Perception of shared repertoire was measured with three items (for example: "this team takes time to discuss how we communicate"). Perception of joint enterprise was measured with six items (for example: "differences in educational perspectives in this team are utilised"). A five-point Likert scale ranging from "agree" to "disagree" was used. Response rate was 85 per cent $(N=72)$. A principal component analysis was conducted on all items with oblique rotation. The analysis showed that three components had Eigenvalues over Kaiser's criterion of 1 and in combination explained 64 per cent of the item variance. Reliability (Cronbach's alpha) of the dimension scores was acceptable: mutual engagement, $\alpha=0.90$, shared repertoire, $\alpha=0.74$, joint enterprise, $\alpha=0.83$.

\begin{tabular}{|c|c|c|c|c|c|}
\hline \multirow[b]{2}{*}{ Dimension } & \multirow[b]{2}{*}{ Item } & \multicolumn{2}{|c|}{$\mathrm{M}^{\mathrm{a}}$} & \multicolumn{2}{|c|}{$\mathrm{SD}^{\mathrm{a}}$} \\
\hline & & T0 & $\mathrm{T} 1$ & T0 & $\mathrm{T} 1$ \\
\hline \multirow[t]{6}{*}{ Mutual engagement } & 1. There is good team spirit in this team & 3.38 & 3.26 & 0.99 & 1.12 \\
\hline & 2. I am proud being part of this team & 3.82 & 3.54 & 0.90 & 0.97 \\
\hline & 3. I feel loyal to the people in this team & 4.16 & 3.87 & 0.71 & 0.77 \\
\hline & 4. I really care about the fate of this team & 3.95 & 3.74 & 0.81 & 0.83 \\
\hline & 5. This team feels like a community & 3.27 & 3.15 & 1.10 & 1.11 \\
\hline & $\begin{array}{l}\text { 6. There is a real sense of community in this } \\
\text { team }\end{array}$ & 3.37 & 3.21 & 0.98 & 1.17 \\
\hline \multirow[t]{2}{*}{ Shared repertoire } & $\begin{array}{l}\text { 7. This team takes time to discuss how we } \\
\text { communicate } \\
\text { 8. This team takes time to reflect and discuss }\end{array}$ & 2.91 & 2.92 & 1.14 & 0.94 \\
\hline & $\begin{array}{l}\text { 9. During meetings, people call for a "time } \\
\text { out" when necessary to deal with potential } \\
\text { problems so certain individuals do not go } \\
\text { on feeling hurt or unheard }\end{array}$ & 2.69 & 2.47 & 1.11 & 0.89 \\
\hline \multirow[t]{7}{*}{ Joint enterprise } & 10. Differences in educational perspectives in & & & & \\
\hline & $\begin{array}{l}\text { this team are utilised } \\
\text { 11. I benefit from the skills and knowledge of }\end{array}$ & 3.31 & 3.33 & 0.92 & 0.93 \\
\hline & $\begin{array}{l}\text { my coworkers from this team } \\
\text { 12. Being part of this team supports me in my }\end{array}$ & 3.60 & 3.49 & 0.88 & 0.89 \\
\hline & $\begin{array}{l}\text { work } \\
\text { One of the ways we move forward in this }\end{array}$ & 3.53 & 3.33 & 1.08 & 1.16 \\
\hline & $\begin{array}{l}\text { team is by using shared ideas } \\
\text { 14. We discuss each others' educational beliefs }\end{array}$ & 3.74 & 3.73 & 0.85 & 0.80 \\
\hline & $\begin{array}{l}\text { in an open manner } \\
\text { 15. Membership in this team is meaningful and }\end{array}$ & 3.62 & 3.62 & 0.90 & 0.92 \\
\hline & woluoblo to me & 3.66 & 3.58 & 1.04 & 1.18 \\
\hline
\end{tabular}

Note: ${ }^{\mathrm{a} O n}$ a scale from $1-5$

\section{Community development in the school}

409 
IJEM

26,4

410

To measure teacher behaviour, video observations of the teams were performed and analysed using an observation instrument that was developed by a team of researchers based on Admiraal and Lockhorst (2010). For each team, two meetings were selected from the beginning and end of the school year. The length of the meetings varied from one to two-and-a-half hours. In total, 28 meetings were scored using a scoring form with indicators that were rated on a three-point Likert scale. As a scoring unit consisted of one whole meeting, every indicator was scored once for each meeting.

Each community of practice dimension was measured with four indicators:

(1) mutual engagement: identification, multi-perspective contribution, mutual trust and responsibility, and social ties;

(2) shared repertoire: intellectual building, regulation of interaction, role-taking, and dynamic effort;

(3) joint enterprise: commitment to domain, common ground in concept, collective goal; and

(4) shared knowledge.

The dimension indicators were high inference measures that relied on subjective observer judgment (Land, 1980). Context knowledge about the team was used as a means of supporting the interpretation of the observation data. The observation instrument yielded qualitative descriptions (i.e. illustrative concrete behaviour) as well as quantitative scores for each indicator. Inter-rater agreement between the two raters was determined with Coefficient Kappa (Cohen, 1960), whereby $\kappa=0.66$. As a level of $\kappa=0.60$ is indicated as a minimum of acceptable inter-rater agreement (Eggens and Sanders, 1993), we consider the agreement between both raters sufficient.

In the analysis of the questionnaire data, the degree of mutual engagement, shared repertoire, and joint enterprise were determined by averaging the item scores representing each dimension. In the analysis of the observation data, the degree of mutual engagement, shared repertoire, and joint enterprise were determined by calculating mean scores for each indicator and subsequently for each dimension. Community development was determined by comparing dimension scores of measurements at the beginning and end of the school year for both questionnaire and observation data. Transformed to a scale from $0-1$, changes up to 0.10 were labelled as "no development", changes between 0.11 and 0.25 were labelled as "limited development", and changes larger than 0.25 were labelled as "considerable development”.

3.3.2. Community-building efforts. The teacher teams' community-building efforts were measured by gathering data during the course of the school year, in between the data gathering on the community development. Because existing teacher teams were investigated, data included teacher teams' current community-building efforts as well as the results of previous community-building efforts. Again, two perspectives were used - teachers' perception and observation by relative outsiders. Teacher perception of community-building efforts was measured with individual semi-structured interviews. Perception related to formal and informal collaborative activities that take place between team members. Participants were team leaders and one or two team members, depending on the size of the team. Team leaders were interviewed twice, team members were interviewed once. The interview began with an open question 
about the collaboration in the team. Next, participants were asked about community-building efforts (activities and/or procedures) in the team that supported and/or strengthened the collaboration. The eight community-building principles already listed were used as guiding themes in the interviews. Each interview was recorded and transcribed.

To collect data from the observation perspective, a meeting that took place in the middle of the school year was video recorded. The length of the meetings varied from one to two-and-a-half hours. In total, seven meetings were observed using categories based on the eight community-building principles. The observation instrument yielded qualitative descriptions of community-building efforts for each of the eight community-building principles.

In the analysis of the interviews and video observations, data were categorised according to the eight types of community-building principles. An additional ninth open category was used to include new principles. Categorisation of the data was critically discussed with an outside source, in order to reach consensus. For each team, community-building efforts from interviews and observations were gathered in a table and categorised according to the eight community-building principles. Each community-building effort included a description of the initiator of the effort, i.e. the team, the team leader, and/or the school leader. Using this table, relative frequencies with regard to community-building efforts of each team were determined. To compare community-building efforts across teams, subsequently, for each community-building principle, efforts were gathered in a table. Highly overlapping community-building efforts were merged (e.g. community-building efforts "the team involves all team members when determining their vision" and "the team involves all team members when determining their goals" were merged into one type of effort). Using this second table, we could determine which community-building efforts were common amongst the teacher teams (i.e. undertaken by more than half of the teams).

\section{Empirical findings}

The community development as perceived and observed for each teacher team is described in Table III. No development is depicted with a "0", limited positive and negative development is depicted with a " + " and "-", considerable positive and negative development is depicted with a " ++ " and "- - ". To help interpret teacher teams' absolute community development (column CD), teams' begin levels (column

\begin{tabular}{|c|c|c|c|c|c|c|c|c|c|c|c|c|}
\hline \multirow[b]{3}{*}{ Team } & \multicolumn{4}{|c|}{ Mutual engagement } & \multicolumn{4}{|c|}{ Shared repertoire } & \multicolumn{4}{|c|}{ Joint enterprise } \\
\hline & \multicolumn{2}{|c|}{ Perceived } & \multicolumn{2}{|c|}{ Observed } & \multicolumn{2}{|c|}{ Perceived } & \multicolumn{2}{|c|}{ Observed } & \multicolumn{2}{|c|}{ Perceived } & \multicolumn{2}{|c|}{ Observed } \\
\hline & T0 & $\mathrm{CD}$ & T0 & $\mathrm{CD}$ & T0 & $\mathrm{CD}$ & T0 & $\mathrm{CD}$ & T0 & $\mathrm{CD}$ & T0 & $\mathrm{CD}$ \\
\hline Team 1 & 0.52 & 0 & 0.42 & ++ & 0.43 & 0 & 0.25 & ++ & 0.60 & 0 & 0.46 & ++ \\
\hline Team 2 & 0.78 & - & 0.83 & 0 & 0.55 & 0 & 0.50 & + & 0.71 & 0 & 0.65 & - \\
\hline Team 3 & 0.58 & 0 & 1 & - - & 0.37 & 0 & 0.72 & 0 & 0.63 & 0 & 0.59 & 0 \\
\hline Team 4 & 0.83 & 0 & 1 & 0 & 0.41 & 0 & 0.68 & 0 & 0.68 & 0 & 0.85 & 0 \\
\hline Team 5 & 0.39 & 0 & 0.28 & - & 0.55 & - & 0.47 & 0 & 0.59 & 0 & 0.50 & - \\
\hline Team 6 & 0.55 & 0 & 0.91 & 0 & 0.38 & 0 & 0.44 & ++ & 0.52 & 0 & 0.66 & 0 \\
\hline Team 7 & 0.75 & 0 & 0.97 & 0 & 0.49 & - & 0.69 & + & 0.74 & 0 & 0.74 & D \\
\hline
\end{tabular}

\section{Community development in the school}

411 
IJEM

26,4

412

T0), that is, teams' degree of Mutual engagement, Shared repertoire, and Joint enterprise at the beginning of the school year, are included in Table III (T0).

The results of Table III imply that overall there was little community development according to the perceptions of the teachers. In teams 1, 3, 4, and 6, no community development took place according to the team members. In team 2 , there was limited negative perceived development with regard to Mutual engagement. In teams 5 and 7, there was limited negative development with regard to Shared repertoire. However, the results imply that overall there was some community development according to the observations. In team 1 there was considerable positive observed community development with regard to all three dimensions. In team 3 there was considerable negative community development with regard to Mutual engagement. In team 6 there was considerable positive community development with regard to the dimension Shared repertoire. In teams 2,5 , and 7 , there was limited positive and negative observed community development on one or more dimensions. In team 4 there was no observed community development.

\subsection{Community-building efforts}

The data show that, overall, teacher teams engage with a wide range of community-building principles. With the exception of one team, teacher teams engage in community-building efforts concerning all eight community-building principles. Common efforts are found in each of the eight community-building principles. Common community-building efforts aimed at determining group goals are: the team involves all team members in determining their vision and/or goals.

Common efforts aimed at determining group norms are:

- the team follows implicit rules for engagement;

- the team follows naturally arising rules for engagement;

- team members listen to each other and/or let each other finish;

- team members take each other seriously;

- the team gives the team leader responsibility for taking final decisions;

- the team documents decisions;

- the team discusses decisions during team meetings;

- the team takes decisions democratically; and

- the team involves all team members in decision-making.

Efforts aimed at organising group roles are:

- the team organises roles based on expertise/function and/or interest;

- school leaders organise the leadership role by means of application;

- the team organises the leadership role in team meetings based on function; and

- the team divides the leadership role in team meetings by means of agenda items based on expertise/function and/or responsibility.

Common community-building efforts aimed at stimulating a critical reflective attitude are:

- the team underpins input during team meetings with arguments; and 
- the team evaluates mentor evenings/project weeks/thematic weeks after they take place.

Efforts aimed at developing mutual trust are:

\section{Community development in the school}

413

Efforts aimed at promoting ownership are:

- the team has freedom in developing and/or organising the education;

- the team leader gives team members freedom in the outlining of their task-schedule;

- the team leader and/or team appeal to each other's responsibilities; and

- the team leader makes team members responsible for input with regard to agenda items in team meetings based on function and/or responsibility.

Efforts aimed at promoting perceived interdependence are:

- school leaders provide the team with time to work together on the organisation and development of the education;

- team members discuss pupil-related matters with each other during the team meeting; and

- the team members perform team teaching in the domain and see a lot of each other.

Common community-building efforts aimed at stimulating a collective memory are: the team uses e-mail to communicate and exchange documents.

Overall, the data show that the majority of community-building efforts are undertaken by the team itself, with a smaller amount of community-building efforts undertaken by the school management, i.e. team leaders and/or school leaders (see Table IV). In addition, efforts undertaken by school management are mostly similar for each team. For instance, in six out of seven teacher teams, community-building efforts undertaken by school leaders are aimed at organising group roles, specifically by organising the team leadership role by means of application. In all teacher teams, community-building efforts undertaken by school leaders are aimed at promoting interdependence, specifically by providing teams with time to collaborate on organisation of education and development of educational materials. Last, the findings show that a substantial proportion of community-building efforts are implicit (i.e. not explicitly discussed or named) and/or unconscious (i.e. not intentional). An example of such an effort is "the team follows implicit rules for engagement". Table IV presents an overview of the amount of community-building efforts for each teacher team.

Analysis of the data resulted in new types of community-building efforts by the teacher teams. However, these efforts fitted into the existing eight community-building principles that were used as the analytic framework, which led to a refinement of five of the eight community-building principles (see Table V). 
IJEM
26,4

414

Table IV.

Percentage of community-building efforts for each principle

\begin{tabular}{lrrrrrrr}
\hline Community-building principle & T1 & T2 & T3 & T4 & T5 \\
$\%$ & $\%$ & \multicolumn{1}{c}{$\%$} & T6 & T7 \\
$\%$ & 6 & 9 & 0 & 2 & 14 & 5 & 13 \\
\hline 1. Determine group goals & 24 & 22 & 31 & 25 & 41 & 43 & 24 \\
2. Determine group norms & 18 & 16 & 17 & 12 & 14 & 13 & 10 \\
3. Organise group roles & 12 & 13 & 8 & 14 & 7 & 10 & 15 \\
4. Stimulate a critical reflective attitude & 10 & 18 & 15 & 17 & 3 & 3 & 12 \\
5. Develop mutual trust & 8 & 2 & 10 & 11 & 7 & 13 & 10 \\
6. Promote ownership & 20 & 18 & 15 & 18 & 10 & 13 & 13 \\
7. Promote perceived interdependence & 2 & 2 & 4 & 2 & 3 & 3 & 1 \\
8. Stimulate a collective memory & 100 & 100 & 100 & 100 & 100 & 100 & 100 \\
9. Total & 82 & 84 & 81 & 75 & 62 & 85 & 87 \\
Efforts team & 12 & 11 & 15 & 22 & 31 & 10 & 10 \\
Efforts team leaders & 6 & 5 & 4 & 3 & 7 & 5 & 3 \\
Efforts school leaders & 100 & 100 & 100 & 100 & 100 & 100 & 100 \\
Total & & & & & & & \\
& & & & & & &
\end{tabular}

Community-building principles

1. Determine group goals

2. Determine group norms

3. Organise group roles

4. Stimulate a critical reflective attitude

5. Develop mutual trust

6. Promote ownership

Table V.

The existing community-building principles and resulting refinement
7. Promote perceived interdependence

8. Stimulate a collective memory
Refinement of principles

Develop guidelines for dealing with decision-making Develop agreements on non-functional behaviour Organise leadership roles

Enable a positive and/or safe atmosphere Support social and/or non-task interaction

Promote collaboration

Promote equality between team members

Promote knowledge of and/or involvement in each other's practice

Provide ICT tools that support communication

\section{Conclusions}

Our first research question concerned the degree to which community development of teacher teams takes place. We discuss our main finding.

\subsection{Community development of the seven teacher teams is modest}

There was limited community development according to the teachers' perceptions. However, from the observations it was shown that there was some observed community development. In three of the seven teams there was substantial community development with regard to one or more community of practice dimensions. However, not all development indicated an increase in degree of Mutual engagement, Shared repertoire, and Joint enterprise, that is, positive as well as negative community development was found. Overall, the teacher teams' degree of Mutual engagement, Shared repertoire and Joint enterprise did not change much. In some cases, limited community development could be explained by a "ceiling effect". This may apply to the perceived Mutual engagement of teams 2, 4, 6, and 7. Due to these teams' high 
dimension scores at the beginning of the school year, the development space of these teams was rather limited. Overall, the limited community development does not match with studies that emphasise the dynamic ever-changing nature of communities of practice. For instance, it is suggested by Weick and Quinn (1999) that the change process is continuous, and can be viewed as a series of fast mini-episodes of change. It may be possible that these continuous mini-episodes of change are hard to measure with the instruments and/or the level of analysis that was used in the current study. Another possible explanation for our main finding could be that as a relatively new way of organising secondary education schools, teaming is a challenge for teachers and school management. Maybe collaboration in teams is mostly functional as opposed to being an integrated part of the team and school culture. After all, in the relatively new school that was investigated, the majority of teachers come from a more autonomous school culture. The big exception to our finding is team 1, which showed considerable observed community development on all three dimensions. This team's diverging results could be explained by the fact that the team started the school year with the highest amount of new team members. This "imbalance" in composition, interpersonal relations, and social processes at the beginning of the year, probably resulted in more changes than in other teams.

Our second research question led us to investigate the extent to which teacher teams engage in the eight community-building principles - and perhaps other principles. Findings lead us to conclude the following.

\subsection{In spite of limited support by school management, teacher teams undertake a considerable amount and range of community-building efforts}

It is generally acknowledged by scholars and practitioners that team development processes benefit from the support of school management. The teacher teams in our study undertake a wide variety of community-building efforts. All community-building principles are part of the teams' repertoire. This repertoire offers cues for support by school management. In addition, teams undertake a substantial amount of community-building efforts. We may conclude that, in large measure, teacher teams already know how to go about the process of building community.

The theoretical added value of this study is twofold. One, it offers a validation of the community-building principles from literature. Two, it offers a refinement of the community-building principles that were used as the analytic framework. Methodological added value concerns the use of observations of behaviour in addition to teacher perceptions.

It is apparent from the data that there is no direct link between community-building efforts and community development of the seven teacher teams. This study originally set out to explore this link. Based on studies, we expected to find that community-building efforts undertaken by teacher teams would relate to their community development. We were not able to investigate this in more detail, as there was limited variation in community development between teacher teams. However, in the majority of these studies, the effectiveness of community-building efforts is not empirically underpinned and empirical evidence of the effectiveness of community-building efforts (how and why efforts work and under what conditions) is limited. The current study does not seem to yield evidence that contributes to closing this gap.

\section{Community development in the school}

415 
IJEM

26,4

416
Two aspects of our study limit its conclusions. The first aspect is the generalisability of the findings, since this was a small-scale study. By carefully selecting appropriate cases and making our selection criterion explicit, we tried to clearly define the limits for generalising the findings (Eisenhardt, 1989). The second aspect is that community development was based on measurements at the beginning and end of a school year. More interim measurements of the degree of community could result in a more dynamic display of community development.

The study has some practical implications for school managers, from the perspective that communities of practice can be a management strategy for fostering collaboration of teams with mutual task responsibility. The findings seem to imply that school managers (i.e. school leaders and team leaders) could play a more proactive role in supporting the teacher teams' community-building efforts. Specifically, administrative arrangements should include the following aspects. The first aspect is for school management to investigate what community-building efforts teacher teams already engage in. Instruments from the current study provide a suitable basis for the development of a self-audit tool to monitor community building. Subsequently, school management can diagnose teacher teams' strong and weak points in community building. The second aspect is for school management to use a custom-made approach in supporting teacher teams' community-building efforts. Not all teams will benefit from the same community-building efforts, as each team has its own culture and composition. Besides, establishing a good fit between management support and the needs of each teacher team can foster ownership on behalf of the teachers, thus increasing the potential for the support to be implemented and/or accepted (McKenney and Van den Akker, 2005). The third aspect is that school management should support mechanisms for making community-building efforts in teacher teams explicit as well as conscious. Strategies could involve a meaningful dialogue between team members in which the use of metaphors can be used to enable team members to articulate their own perspectives (Nonaka, 1994), experiences, and vision of community building. These arrangements could help school management to embed community building into the culture and policy of the school.

Future research can enhance our understanding of the issues raised in our research questions. Research is recommended to focus on empirically investigating the effectiveness of community-building efforts to enhance insights into which efforts work and which do not, as well as how they work (the underlying mechanisms). Design-based research seems be a suitable research approach. In addition, research could focus on adapting the instruments used in this study into tools that are suitable for school managers to diagnose the status quo of teacher teams' community development.

\section{References}

Achinstein, B. (2002), "Conflict amid community: the micropolitics of teacher collaboration", Teachers College Record, Vol. 104 No. 3, pp. 421-55.

Admiraal, W. and Lockhorst, D. (2010), “A descriptive model of teacher communities”, paper presented at the annual meeting of the American Educational Research Association, Denver, CO, May.

Bolam, R., McMahon, A., Stoll, L., Thomas, S. and Wallace, M. (2005), "Creating and sustaining effective professional learning communities", University of Bristol, Bristol. 
Burroughs, S.M. and Eby, L.T. (1998), "Psychological sense of community at work: a measurement system and explanatory framework", Lournal of Community Psychology, Vol. 26 No. 6, pp. 509-32.

Cohen, J. (1960), “A coefficient of agreement for nominal scales”, Educational and Psychological Measurement, Vol. 20 No. 37, pp. 37-46.

Conley, S., Fauske, J. and Pounder, D.G. (2004), “Teacher work group effectiveness”, Educational Administration Quarterly, Vol. 40 No. 5, pp. 663-703.

Darling-Hammond, L. and McLaughlin, M.W. (1995), "Policies that support professional development in an era of reform", Phi Delta Kappan, Vol. 76 No. 8, pp. 597-604.

Eggens, T.J.H.M. and Sanders, P.F. (1993), Psychometrie in de Praktijk ((Psychometrics in Practice)), CITO, Arnhem.

Eisenhardt, K.M. (1989), "Building theories from case study research", Academv of Management Review, Vol. 14 No. 4, pp. 532-50.

Grossman, P., Wineburg, S. and Woolworth, S. (2001), "Toward a theory of teacher community", Teachers College Record, Vol. 103 No. 6, pp. 942-1012.

Hargreaves, A. and Dawe, R. (1990), "Paths of professional development: contrived collegiality, collaborative culture, and the case of peer coaching", Teaching \& Teacher Education, Vol. 6 No. 3, pp. 227-41.

Hindin, A., Morocco, C.C., Mott, E.A. and Aquilar, C.M. (2007), "More than just a group: teacher collaboration and learning in the workplace", Teachers and Teaching: Theory and Practice, Vol. 13 No. 4, pp. 349-76.

Imants, J. (2003), "Two basic mechanisms for organizational learning in schools", European Iournal of Teacher Education, Vol. 26 No. 3, pp. 293-311.

James, C.R., Dunning, G., Connolly, M. and Elliott, T. (2007), "Collaborative practice: a model of successful working in schools", Iournal of Educational Administration, Vol. 45 No. 5, pp. 541-55.

Johnson, R.B. and Onwuegbuzie, A.J. (2004), "Mixed methods research: a research paradigm whose time has come", Educational Researcher, Vol. 33 No. 9, pp. 14-26.

Kain, D.L. (1998), Camel-Makers: Building Effective Teacher Teams Together: A Modern Fable for Educators, National Middle School Association, Westerville, $\mathrm{OH}$.

Land, M.L. (1980), "The name assigned to the document by the author. This field may also contain sub-titles, series names, and report numbers. Teacher clarity and cognitive level of questions: effects on learning”, Lournal of Experimental Education, Vol. 49 No. 1, pp. 48-51.

Lave, J. and Wenger, E. (1991), Situated Learning. Legitimate Peritheral Particitation, University of Cambridge Press, Cambridge.

Levine, T.H. and Marcus, A.S. (2010), "How the structure and focus of teachers' collaborative activities facilitate and constrain teacher learning", Teaching and Teacher Education, Vol. 26, pp. 389-98.

Li, L.C., Grimshaw, J.M., Nielsen, C., Judd, M., Coyte, P.C. and Graham, I.D. (2009), "Evolution of Wenger's concept of community of practice”, Implementation Science, Vol. 4 No. 11, pp. 1-8.

Little, J.W. (1990), "The persistence of privacy: autonomy and initiative in teachers' professional relations", Teachers College Record, Vol. 91 No. 4, pp. 509-36.

Lomos, C., Hofman, R.H. and Bosker, R. (2011), "Professional communities and student achievement - a meta-analysis", School Effectiveness and School Improvement, Vol. 22 No. 2, pp. 121-48.

Louis, K.S., Marks, H. and Kruse, S. (1996), "Teachers' professional community in restructuring schools", American Educational Research Journal, Vol. 33 No. 4, pp. 757-98. 
IJEM

26,4

418
McKenney, S. and Van den Akker, J. (2005), "Computer-based support for curriculum designers: a case of developmental research", Educational Technology Research and Development, Vol. 53 No. 2, pp. 41-66.

Nonaka, I. (1994), “A dynamic theory of organizational knowledge creation”, Organization Science, Vol. 5 No. 1, pp. 14-37.

Palincsar, A.S., Magnusson, S.J., Marano, N., Ford, D. and Brown, N. (1998), "Designing a community of practice: principles and practices of the GIsML community", Teaching and Teacher Education, Vol. 14 No. 1, pp. 5-19.

Seashore, K.R., Anderson, A.R. and Riedel, E. (2003), "Implementing arts for academic achievement: the impact of mental models, professional community and interdisciplinary teaming", paper presented at the Seventeenth Conference of the International Congress for School Effectiveness and Improvement, Rotterdam, 6-9 January.

Skerrett, A. (2010), “There's going to be community. There's going to be knowledge': designs for learning in a standardised age", Teaching and Teacher Education, Vol. 26, pp. 648-55.

Vescio, V., Ross, D. and Adams, A. (2008), "A review of research on the impact of professional learning communities on teaching practice and student learning", Teaching and Teacher Education, Vol. 24, pp. 80-91.

Wageman, R., Hackman, J.R. and Lehman, E. (2005), "Team diagnostic survey: development of an instrument”, Lournal of Applied Behavioral Science, Vol. 41 No. 4, pp. 373-98.

Weick, K.E. (1979), The Social Psychology of Organizing, 2nd ed., Addison-Wesley, Reading, MA.

Weick, K.E. and Quinn, R.E. (1999), "Organizational change and development”, Anmual Review of Psvchologv, Vol. 50 No. 1, pp. 361-86.

Weil, M.O. (1996), “Community building: building community practice”, Social Work, Vol. 41 No. 5, pp. 481-99.

Wenger, E. (1998), Communities of Practice. Learning. Meaning and Identity, Cambridge University Press, Cambridge.

Westheimer, J. (1999), "Communities and consequences: an inquiry into ideology and practice in teachers' professional work", Educational Administration Quarterlv, Vol. 35 No. 1, pp. 71-105.

Wilson, B.G., Ludwig-Hardman, S., Thornam, C.L. and Dunlap, J.C. (2004), "Bounded community: designing and facilitating learning communities in formal courses", International Review of Research in Open and Distance Learning, Vol. 5 No. 3, available at: www.irrodl.org/ index.php/irrodl/article/view/204 (accessed 15 March 2010).

\section{About the authors}

Patricia Brouwer is a PhD Researcher at the Centre for Expertise in Vocational Education and Training. Patricia Brouwer is the corresponding author and can be contacted at: patricia.brouwer@ecbo.nl

Mieke Brekelmans is Professor at Utrecht University, Faculty of Behavioural Sciences.

Loek Nieuwenhuis is Professor at Ruud de Moor Centre, Open University.

Robert-Jan Simons is Professor at the Centre for Teaching and Learning at Utrecht University.

To purchase reprints of this article please e-mail: reprints@emeraldinsight.com Or visit our web site for further details: www.emeraldinsight.com/reprints 


\section{This article has been cited by:}

1. Marco Mazereeuw, Iwan Wopereis, Susan McKenney. 2016. Extended teams in vocational education: collaboration on the border. Educational Research and Evaluation 22:3-4, 194-212. [CrossRef]

2. Hoi Kwan Ning, Daphnee Lee, Wing On Lee. 2016. The relationship between teacher value orientations and engagement in professional learning communities. Teachers and Teaching 22:2, 235-254. [CrossRef]

3. Ilham Nasser, Julie K. Kidd, M. Susan Burns, Trina Campbell. 2015. Head Start classroom teachers' and assistant teachers' perceptions of professional development using a LEARN framework. Professional Development in Education 41:2, 344-365. [CrossRef]

4. Eric C.K. Cheng Department of Curriculum and Instruction, The Hong Kong Institute of Education, Hong Kong SRA, China John C.K. Lee Department of Curriculum and Instruction, The Hong Kong Institute of Education, Hong Kong SRA, China . 2014. Developing strategies for communities of practice. International Journal of Educational Management 28:6, 751-764. [Abstract] [Full Text] [PDF]

5. Esther de Groot, Maaike Endedijk, Debbie Jaarsma, Peter van Beukelen, Robert-Jan Simons. 2013. Development of critically reflective dialogues in communities of health professionals. Advances in Health Sciences Education 18:4, 627-643. [CrossRef] 